\title{
COMPARISON OF STRENGTH AND DURABILITY OF CONCRETES MADE WITH SULFATE-RESISTANT PORTLAND CEMENT AND PORTLAND CEMENT WITH POZZOLANA ADDITIVE
}

\author{
Sergii Kroviakov \\ Odessa State Academy of Civil Engineering and Architecture, Ukraine, Professor \\ Mykhailo Zavoloka \\ Odessa State Academy of Civil Engineering and Architecture, Ukraine, Professor \\ Lidia Dudnik \\ Odessa State Academy of Civil Engineering and Architecture, Ukraine, Eng. \\ Vitalii Kryzhanovskyi \\ Odessa State Academy of Civil Engineering and Architecture, Ukraine, Eng. \\ Corresponding author: vitolloscience@gmail.com
}

\begin{abstract}
In this study, a comparison of the strength and durability of concrete with sulfate-resistant cement and cement with pozzolana additive was performed. In assessing the concrete durability, three indicators were compared: sulfate resistance, water permeability, and frost resistance. All concrete mixtures were used without admixtures. The absence of chemical admixtures in the concrete mixtures was because of the need to compare properly the properties of concretes with different cements without the influence of modifiers, which may result in different efficiencies for different types of binders. The concrete compositions of grades C20/25 and C30/35 were presented. The use of Portland cement with pozzolana additive in concrete mixtures provided the necessary level of corrosion resistance and frost resistance of concrete, as well as higher water permeability and lower cement content in comparison with using sulfate-resistant Portland cement.
\end{abstract}

Keywords: sulfate resistance; pozzolana; sulfate-resistant cement; frost resistance; water permeability; early compressive strength

\section{USPOREDBA ČVRSTOĆE I TRAJNOSTI BETONA IZRAĐENOG S PORTLAND CEMENTOM OTPORNIM NA SULFAT I PORTLAND CEMENTOM S DODATKOM PUCOLANA}

Sažetak: Članak se bavi usporedbom čvrstoće i trajnosti betona izrađenog s cementom otpornim na sulfat i cementom s dodatkom pucolana. Za ocjenu trajnosti betona uspoređena su tri pokazatelja: otpornost na sulfat, vodonepropusnost i otpornost na smrzavanje. Sve betonske smjese bile su bez dodataka. Odsustvo kemijskih primjesa u betonskim mješavinama provedeno je radi pravilne usporedbe svojstava betona izrađenog s različitim cementima, bez utjecaja modifikatora koji mogu imati različit učinak na različite vrste veziva. Dani su betonski sastavi razreda C20/25 i C30/35. Uporaba Portland cementa s dodatkom pucolana u betonskim mješavinama osigurava potrebnu razinu otpornosti betona na koroziju i smrzavanje, kao i veću propusnost vode te manji sadržaj cementa u usporedbi s Portland cementom otpornim na sulfat.

Ključne riječi: sulfatna otpornost; pucolan; sulfatno otporan cement; otpornost na smrzavanje; vodonepropusnost; rana tlačna čvrstoća 


\section{INTRODUCTION}

Sulfate resistance of cement is an essential condition of durability for concrete structures used in contact with an aggressive sulfate environment. This is a primary concern in concretes used in marine hydraulic structures [1]. For structures that are partly immersed in water (such as pales, pier walls, and coastal protection structures), durability is determined by the set of concrete properties. For the part of the structure that is underwater, the sulfate resistance and water permeability of concrete are most important; for the part of the structure that is above water, frost resistance is important, and, in the zone of variable water level, all the three parameters are important, namely, sulfate resistance, water permeability, and frost resistance [2,3]. Therefore, to achieve objectivity in the assessment of concrete durability with various types of cement, it is necessary to compare the whole complex of these properties.

In the modern construction market of Ukraine, there is a certain shortage of nonadditive sulfate-resistant cement. Until 2014, nonadditive sulfate-resistant Portland cement in Ukraine was manufactured only in the Novoamvrosievsky cement factory on a permanent basis. However, since 2015, because of the complete closedown of work at the Novoamvrosievsky cement factory, the Ivano-Frankivsk cement factory has become the only manufacturer of sulfate-resistant Portland cement in Ukraine. The rest of the Ukrainian cement manufacturers offer only sulfate-resistant slag Portland cement in the market, and concrete made with this cement exhibits poor performance in structures subjected to freezing and thawing [4]. Technological features of the manufacturing of nonadditive sulfate-resistant cement with a variable demand for this binder cause certain inconveniences for customers, such as the need to preorder a batch of cement and the limit on the minimum batch size. Imported sulfate-resistant, nonadditive cements in Ukraine are not common and have a cost that is several times higher than that of domestic ones. Accordingly, with small amounts of work using the sulfate-resistant cement, concrete manufacturers cannot always obtain the necessary binder, and may have to wait for its production.

The aforementioned problem can be overcome through the use of an alternative cement, the production of which in large quantities is technologically simpler, while the binder can provide the level of corrosion resistance and frost resistance required by most structures. As research has demonstrated [3, 5-11], Portland cement with pozzolana additive can be used as an alternative to sulfate-resistant Portland cement, and concretes made with this cement are characterized by high sulfate resistance and satisfactory frost resistance.

\section{MATERIALS AND METHODS}

The purpose of this study was to compare the compressive strength, frost resistance, water permeability, and sulfate resistance of concretes made with sulfate-resistant Portland cement CEM I 32.5 R/SR and Portland cement with pozzolana additive CEM II/A-P 42.5 R. Both cements are manufactured by ZAO Ivano-Frankivsk Cement (CJSC).

For this comparison, a design-experimental method was used, and the design of four concrete mixtures was conducted:

- grade $\mathrm{C} 20 / 25$ on sulfate-resistant Portland cement;

- grade C20/25 on Portland cement with pozzolana additive;

- grade C30/35 on sulfate-resistant Portland cement; and

- grade C30/35 on Portland cement with pozzolana additive.

All the concrete mixtures were used without chemical admixtures and had an equal slump $(5-10 \mathrm{~cm})$. In each test series, 48 samples were produced.

The following materials were used as aggregates for the concretes. Washed quartz sand $(2.5-5 \mathrm{~mm}-8 \%$, $1.25-2.5 \mathrm{~mm}-8.7 \%, 0.63-1.25 \mathrm{~mm}-25.4 \%, 0.315-0.63 \mathrm{~mm}-37.5 \%, 0.16-0.315 \mathrm{~mm}-20 \%$, and $<0.16 \mathrm{~mm}-$ $0.4 \%$ ) had a bulk density of $1480 \mathrm{~kg} / \mathrm{m}^{3}$. Granite crushed stone was of grade $5-20 \mathrm{~mm}$, with a bulk density of 1390 $\mathrm{kg} / \mathrm{m}^{3}$. The content of dust particles in crushed stone was $0.2 \%$.

The concrete mixtures are presented in Table 1. For each concrete grade, one concrete mixture was selected for the sulfate-resistant Portland cement, and the other for the Portland cement with pozzolana additive. Because of the different activities of the binders while ensuring a given grade of concrete, the estimated cement content per $\mathrm{m}^{3}$ of the mixture was $20 \mathrm{~kg}$ lesser in comparison with that of sulfate-resistant Portland cement. This is because Portland cement with pozzolana additive has a higher activity in comparison with sulfate-resistant Portland cement.

Kroviakov, S, Zavoloka, M, Dudnik, L, Kryzhanovskyi, V 
Comparison of strength and durability of concretes made with sulfate-resistant Portland cement and Portland cement with pozzolana additive

For all the selected concrete mixtures, the following were determined: compressive strength at the ages of 7 , 28,90 , and 180 days, water permeability, frost resistance, water absorption, and corrosion resistance in a liquid sulfate environment.

Table 1 Concrete mixtures with various types of Portland cement (slump 5-10 cm, maximum crushed stone grade $20 \mathrm{~mm}$ )

\begin{tabular}{cccccc}
\hline $\begin{array}{c}\text { Concrete grade and type of Portland } \\
\text { cement }\end{array}$ & $\begin{array}{c}\text { Cement } \\
\text { content, } \mathbf{~ k g} / \mathbf{m}^{3}\end{array}$ & $\begin{array}{c}\text { Crushed } \\
\text { stone, } \mathbf{~ k g} / \mathbf{m}^{3}\end{array}$ & $\begin{array}{c}\text { Quartz sand, } \\
\mathbf{~ k g} / \mathbf{m}^{3}\end{array}$ & $\begin{array}{c}\text { Water, } \\
\mathbf{l} / \mathbf{m}^{3}\end{array}$ & W/C \\
\hline C20/25 with sulfate-resistant Portland cement & 331 & 1190 & 701 & 178 & 0,538 \\
C20/25 with Portland cement with pozzolana & 311 & 1202 & 712 & 176 & 0,566 \\
$\begin{array}{c}\text { additive } \\
\text { C30/35 with sulfate-resistant Portland cement }\end{array}$ & 433 & 1179 & 585 & 202 & 0,467 \\
C30/35 with Portland cement with pozzolana & 413 & 1187 & 606 & 190 & 0,460 \\
\hline \begin{tabular}{c} 
additive \\
\hline
\end{tabular}
\end{tabular}

Figure 1 illustrates the dynamics of the compressive strength gain for the four investigated concrete mixtures at the ages of $7,28,90$, and $180 \mathrm{~d}$.

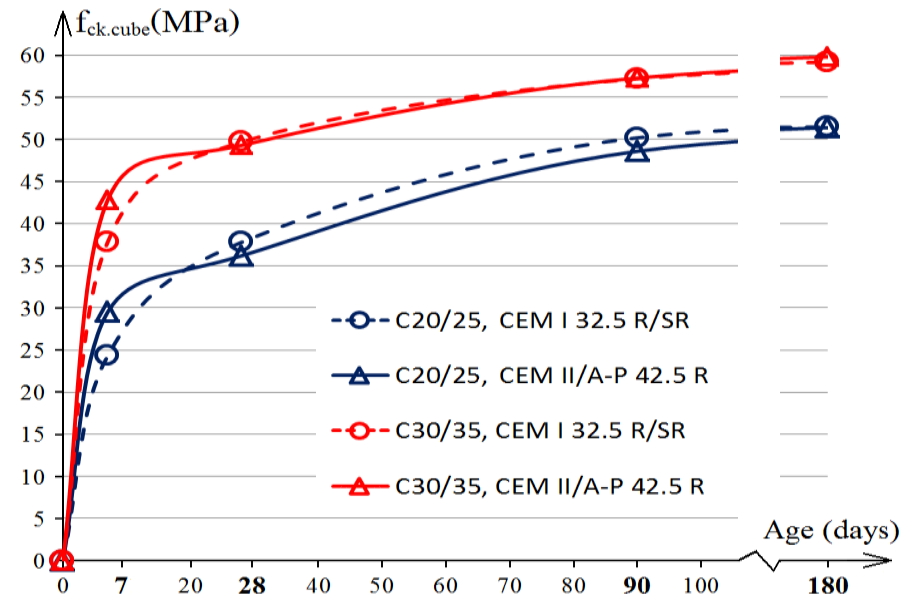

Figure 1 Compressive strength of the investigated concretes at the ages of 7, 28, 90, and $180 \mathrm{~d}$

\section{RESULTS AND DISCUSSION}

Because of the binder composition, it was expected that the compressive strength of concretes with Portland cement with pozzolana additive at the age of $7 \mathrm{~d}$ would be higher than that of similar concrete grades with sulfateresistant Portland cement. At the age of $28 \mathrm{~d}$, based on the experimental conditions, the compressive strength of all the concretes corresponded to their grade.

A further compressive strength increase of concretes on various types of cement elapsed at approximately the same pace. At the age of $90 \mathrm{~d}$, the compressive strength of concrete grade $\mathrm{C} 20 / 25$ was higher than the 28-day compressive strength by $33-35 \%$, and the compressive strength of concrete grade $\mathrm{C} 30 / 35$ during this period increased by $15-16 \%$. At the age of $180 \mathrm{~d}$, the compressive strength of concrete grade C20/25 was higher than the 28-day compressive strength by $36-42 \%$, and the compressive strength of concrete grade $\mathrm{C} 30 / 35$ during this period increased by $19-21 \%$.

The values of frost resistance, water permeability, and water absorption of the four investigated concrete mixtures are listed in Table 2. 
Comparison of strength and durability of concretes made with sulfate-resistant Portland cement and Portland cement with pozzolana additive

Table 2 Frost resistance, water permeability, and water absorption of investigated concretes with various types of cement

\begin{tabular}{cccc}
\hline Concrete grade and type of Portland cement & Frost resistance & Water permeability & Water absorption \\
\hline C20/25 with sulfate-resistant Portland cement & F150 & W6 & $4.8 \%$ \\
C20/25 with Portland cement with pozzolana additive & F150 & W8 & $4.7 \%$ \\
C30/35 with sulfate-resistant Portland cement & F200 & W10 & $5.0 \%$ \\
C30/35 with Portland cement with pozzolana additive & F200 & W12 & $4.7 \%$ \\
\hline
\end{tabular}

The analysis of the data in the table reveals that the frost resistance of the same concrete grade with different types of cement was the same: 150 cycles for concrete grade C20/25 and 200 cycles for concrete grade C30/35. The frost resistance was determined by the second accelerated method (i.e., the samples were frozen in air, saturated with sodium chloride, and subsequently thawed in a solution of sodium chloride) according to Ukrainian building code DSTU B V.2.7-49-96. When the frost resistance was determined by the accelerated method, the levels of this quality indicator for concretes with different types of cement did not differ.

The water permeability of concrete, determined by the wet-spot method (measurement of the maximum pressure at which the sample does not leak water) according to Ukrainian building code DSTU B V.2.7-170-2008, depended on the concrete grade and cement type that was used in the concrete. Concretes of grade C20/25 have a naturally lower water permeability (W6 and W8), whereas concretes of grade C30/35 have a higher water permeability (W10 and W12). The concretes with Portland cement with pozzolana additive exhibited a water resistance one grade higher than that of similar concrete grades with sulfate-resistant Portland cement. In this case, the water absorption of all the four investigated concretes was approximately at the same level (4.7-5\%).

However, as indicated above, the main reason for using sulfate-resistant Portland cement for concrete is the need to resist the aggressive effects of sulfates in the operating environment for which the structure is being produced. Consequently, when considering Portland cement with pozzolana additive as an alternative to sulfateresistant Portland cement, it is necessary to compare the corrosion resistance of concrete with these two cements in an aggressive sulfate environment.

The study of concrete corrosion resistance in a liquid aggressive environment was conducted according to the Ukrainian building code. The sulfate medium with an $\mathrm{SO}_{4}{ }^{2-}$ concentration of $10,000 \mathrm{mg} / \mathrm{l}$ (solution of $\mathrm{Na}_{2} \mathrm{SO}_{4}$ ) was considered as aggressive. The compressive strength of the samples was controlled after exposure in an aggressive environment for 1,3 , and 6 months, and samples of the same age were controlled after exposure to fresh water. According to these data, the coefficients of concrete resistance in an aggressive environment were calculated (Table 3).

Table 3 Determination of concrete corrosion resistance in a liquid aggressive sulfate environment

\begin{tabular}{|c|c|c|c|c|c|c|c|c|c|}
\hline \multirow[b]{2}{*}{$\begin{array}{l}\text { Concrete grade and type } \\
\text { of Portland cement }\end{array}$} & \multicolumn{3}{|c|}{ 1-month exposure } & \multicolumn{3}{|c|}{ 3-months exposure } & \multicolumn{3}{|c|}{ 6-months exposure } \\
\hline & 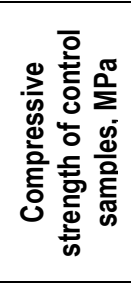 & 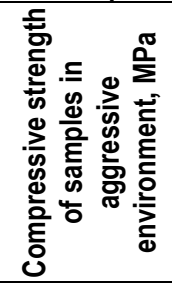 & 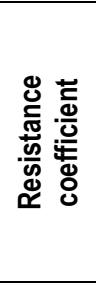 & 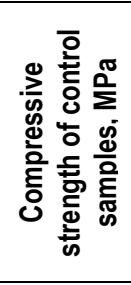 & 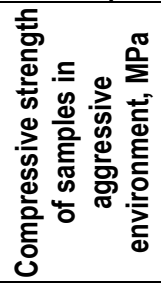 & 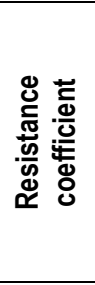 & 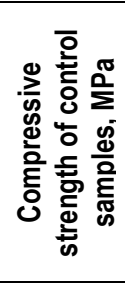 & 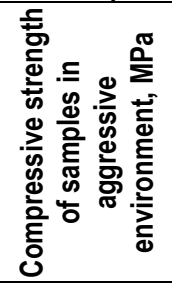 & 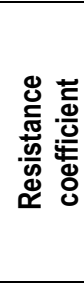 \\
\hline $\begin{array}{l}\text { C20/25 with sulfate-resistant } \\
\text { Portland cement }\end{array}$ & 4.9 & 44.0 & 0.981 & 47.2 & 47.8 & 1.013 & 53.6 & 53.8 & 1.004 \\
\hline $\begin{array}{l}\text { C20/25 with Portland cement } \\
\text { with pozzolana additive }\end{array}$ & 41.2 & 39.9 & 0.968 & 44.2 & 44.1 & 0.998 & 48.8 & 46.2 & 0.947 \\
\hline $\begin{array}{c}\text { C30/35 with sulfate-resistant } \\
\text { Portland cement }\end{array}$ & 52.7 & 54.8 & 1.041 & 55.1 & 57.9 & 1.051 & 62.7 & 66.1 & 1.054 \\
\hline $\begin{array}{l}\text { C30/35 with Portland cement } \\
\text { with pozzolana additive }\end{array}$ & 52.9 & 55.6 & 1.051 & 55.7 & 58.3 & 1.047 & 62.2 & 61.1 & 0.982 \\
\hline
\end{tabular}

The analysis of the data in the table reveals that all the investigated concretes exhibited approximately the same level of stability in a liquid sulfate environment. The resistance coefficient for concretes of grade C20/25 after 1,3 , and 6 months of sample exposure in $\mathrm{SO}_{4}{ }^{2-}$ solution with a concentration of $10000 \mathrm{mg} / \mathrm{l}$ was $0.947-1.013$, 
Comparison of strength and durability of concretes made with sulfate-resistant Portland cement and Portland cement with pozzolana additive

and that for the concretes of grade $\mathrm{C} 30 / 35$ was $0.982-1.054$, which is almost equal to one unit, given the statistical accuracy of the method. In other words, the compressive strength of the investigated concretes in water and in a sulfate environment changed at approximately the same rate.

Thus, research has demonstrated that concretes with Portland cement with pozzolana additive exhibit higher frost resistance and corrosion resistance in an aggressive sulfate environment in comparison with those of concretes of a similar grade with sulfate-resistant Portland cement, in addition to having a higher water permeability. Such quality indicators were obtained in the study of concretes of the same grades, and not with the same amount of binder. In other words, without considering that the concretes with Portland cement with pozzolana additive had a lower cement consumption per $\mathrm{m}^{3}$ in comparison with similar concrete grades with sulfate-resistant Portland cement, it was confirmed that using Portland cement with pozzolana additive is a promising alternative to sulfateresistant Portland cement in concretes used in contact with an aggressive liquid sulfate environment with simultaneous freezing and thawing. For accurately determining this ability, it is desirable to conduct additional research on the concrete properties of the above-mentioned types of cement in natural conditions. Furthermore, it is intended to conduct experiments on similar concrete mixtures modified with polycarboxylate additives.

\section{CONCLUSIONS}

Four concrete mixtures were designed in this study: concrete grade C20/25 with Portland cement with pozzolana additive and with sulfate-resistant Portland cement, and concrete grade C30/35 with the same cements. For concretes without chemical admixtures, the slump of the concrete mixtures was $5-10 \mathrm{~cm}$, and the maximum size of the crushed stone was $20 \mathrm{~mm}$. Because of the different activities of the binders, while ensuring a given grade of concrete, the estimated consumption of Portland cement with pozzolana additive per $\mathrm{m}^{3}$ of the mixture was $20 \mathrm{~kg}$ lesser than the designed consumption of sulfate-resistant Portland cement.

The compressive strength of the concretes with Portland cement with pozzolana additive at the age of $7 d$ was higher than that of similar concrete grades with sulfate-resistant Portland cement. At the age of $28 \mathrm{~d}$, based on the experimental conditions, the compressive strength of all the concretes corresponded to their grade. A further increase in the concrete compressive strength with various types of cement occurred at approximately the same pace.

The concretes with Portland cement with pozzolana additive were one grade more water resistant than the same grade concretes with sulfate-resistant Portland cement.

The concretes with Portland cement with pozzolana additive and concretes with sulfate-resistant Portland cement exhibited the same frost resistance (when determining index $\mathrm{F}$ by the accelerated method).

The concretes with Portland cement with pozzolana additive and concretes with sulfate-resistant Portland cement exhibited approximately the same level of stability in a liquid sulfate environment with an $\mathrm{SO}_{4}{ }^{2-}$ concentration of $10000 \mathrm{mg} / \mathrm{l}\left(\mathrm{Na}_{2} \mathrm{SO}_{4}\right.$ solution) after 1, 3, and 6 months of sample exposure.

These results demonstrate the ability of using Portland cement with pozzolana additive as an alternative to sulfate-resistant Portland cement in concretes that are used in contact with an aggressive liquid sulfate environment with simultaneous freezing and thawing.

\section{References}

[1] Holland, R.B., Kurtis, K.E., Kahn, L.F. 2017: Sulfate resistance of ternary blend concretes: Influence of binder composition on performance. American Concrete Institute, ACI Special Publication. 317, pp. 1-14

[2] Marine Concrete Structures: Design, Durability and Performance. Mark Alexander (ed.), 2016, p. 504

[3] Kwon, S.-J.; Lee, H.-S.; Karthick, S.; Saraswathy, V.; Yang, H.-M. 2017: Long-term corrosion performance of blended cement concrete in the marine environment - A real-time study. Construction and Building Materials. 154, pp. 349-360, https://doi.org/10.1016/i.conbuildmat.2017.07.237

[4] Dvorkin L.I.; Dvorkin O.L. 2013: Stroitelnye mineralnye vyazhushie materialy. M.: Infra-Inzheneriya, p. 544 (in Ukrainian)

[5] Sanitsky, M.A.; Kropyvnytska, T.P.; Gevyuk, I.N.; Kotiv, M.V. 2016: Betoni polifunkcionalnogo priznachennya na osnovi kompozicijnikh ceolitvmisnikh portlandcementiv. Visnik Nacionalnogo universitetu "Lvivska politekhnika". "Teoriya I praktika budivnictva". № 844. p. 188-193 (in Ukrainian) 
Comparison of strength and durability of concretes made with sulfate-resistant Portland cement and

Portland cement with pozzolana additive

[6] Fodil, D.; Mohamed, M. 2018: Compressive strength and corrosion evaluation of concretes containing pozzolana and perlite immersed in aggressive environments. Construction and Building Materials. 179, pp. 25-34, https://doi.org/10.1016/i.conbuildmat.2018.05.190

[7] Massazza, F. 1993: Pozzolanic cements. Cement and Concrete Composites. 15 (4), pp. 185-214, https://doi.org/10.1016/0958-9465(93)90023-3

[8] Sengül Ö. Effects of pozzolanic materials 0 the mechanical properties and chloride diffusivity of concrete. $\mathrm{PhD}$ thesis, Istanbul Technical University, Istanbul, 2005

[9] Senhadji, Y.; Escadeillas, G.; Khelafi, H.; Mouli, M.; Benosman, A.S. 2012: Evaluation of natural pozzolan for use as supplementary cementitious material. European Journal of Environmental and Civil Engineering, 16 (1), pp. 77-96, https://doi.org/10.1080/19648189.2012.667692

[10] Jain, N. 2012: Effect of nonpozzolanic and pozzolanic mineral admixtures on the hydration behavior of ordinary Portland Cement. Construction and Building Materials, 27 (1), pp. 39-44, https://doi.org/10.1016/i.conbuildmat.2011.08.006

[11] Setina, J.; Krage, L.; Juhnevica, I.; Shakhemko, G. 2012: The influence of different pozzolanic admixtures on structure and properties of concrete, Proceedings of the 18th International Baustofftagung ibausil' 2012, $12-$ 15. September, 2012, Weimar, Germany, pp. 2-0154-2-0161

Please cite this article as:

Kroviakov, S.; Zavoloka, M.; Dudnik, L.; Kryzhanovskyi, V.: Comparison of strength and durability of concretes made with sulfate-resistant Portland cement and Portland cement with pozzolana additive, Electronic Journal of the Faculty of Civil Engineering Osijek-e-GFOS, 2019, 19, pp. 81-86, https://doi.org/10.13167/2019.19.8 